\title{
Legal Hierarchies in the Works of Hans Kelsen and Adolf Julius Merkl
}

\author{
Thomas Olechowski
}

\section{Contents}

References.

\begin{abstract}
At Austrian universities, the problem of 'Precedence of Constitution' is usually taught within the framework of the 'theory of the hierarchical structure of the legal order', an essential part of the so-called 'Pure Theory of Law.' Whilst the famous jurist Hans Kelsen (1881-1973) was the founder of the Pure Theory, the 'theory of the hierarchical structure' has been introduced by Kelsen's disciple Adolf J. Merkl (1890-1970) in 1918 and is accepted also by those who do not follow Kelsen's Pure Theory. According to the Pure Theory, the basis of the validity of a norm can only be another norm, which can be seen as the 'higher' norm. The legal order can be seen as a structure of 'higher' and 'lower' norms, and within the legal order of a certain state, its constitution is the highest norm of all - the 'paramount law', as has been said by US Supreme Court in its famous case Marbury v. Madison, in 1803. The 'theory of the hierarchical structure' also gives the justification for constitutional justice: the constitutional court reviews whether the legislator has remained within the framework of the constitution.
\end{abstract}

'Precedence of Constitution' or, in German, Verfassungsvorrang, the phrase which is in the centre of this conference, is hardly ever used in the Austrian legal language, even almost unknown. The problem discussed here, which is the question of the relationship of the constitution to other norms, in particular to statutes, is usually taught at Austrian universities within the framework of the 'theory of the hierarchical structure of the legal order'-in German: Lehre vom Stufenbau der Rechtsordnung.

\footnotetext{
T. Olechowski ( $\square)$

University of Vienna, Vienna, Austria

e-mail: thomas.olechowski@univie.ac.at

(C) The Author(s) 2018

U. Müßig (ed.), Reconsidering Constitutional Formation II Decisive Constitutional 
This theory is recognised as so fundamental that it is already taught to students in their first semester, albeit in very simplified manner, which does not really reflect the revolutionary character that the theory had in the days when it was first developed. ${ }^{1}$ At any rate this theory is common sense in the Austrian scientific community. This is true not only for the followers of Hans Kelsen's 'Pure Theory of Law', which continues to be quite popular in Austria, but also for its critics. Just a short while ago it was argued that the 'hierarchical structure of the legal order [was] the most important achievement of the Vienna School of Legal Theory, and indeed its only element that was not built on sand but stands on solid ground.' Hardly ever do people remember that the theory of the hierarchical structure was not developed by Hans Kelsen, and that, in fact, Kelsen had originally intended to banish as non-juristic from his theory of law the central problem which is resolved by the theory of the hierarchical structure, which is the question of the formation and annulment of legal norms. ${ }^{3}$ It was his disciple Adolf Julius Merkl, who from 1918 onward developed the first ideas in this regard, ${ }^{4}$ and thereby made such an important contribution to Kelsen's Pure Theory of Law that Merkl was even 'crowned' co-founder of the Pure Theory by his academic teacher. ${ }^{5}$ However, it remained Kelsen's task to connect the theory of the hierarchical structure with the other propositions of the Pure Theory of Law and to integrate it into his theorem in such a skilful way that it would hardly occur to latter-day readers that it had not been part of this theory from the beginning. ${ }^{6}$

From what has been said so far, one can infer that the theory of the hierarchical structure, even if it is nowadays often taught independently of more detailed theoretical considerations, can only be fully understood if it is elaborated against the backdrop of Kelsen's Pure Theory of Law. This will be briefly addressed in the following.

The vantage point of the Pure Theory of Law is the difference between 'is' and 'ought': With the sentence 'A certain state of affairs exists', we express something completely different than with the sentence 'A certain state of affairs ought to exist.' The first sentence is a statement about the actual state of affairs; the latter sentence is a normative order, a norm. ${ }^{7}$ Admittedly, it is often the case that the content of a norm corresponds to an actual state of affairs, so that what ought to be does actually

\footnotetext{
${ }^{1}$ See f.e. Kneihs et al. (2014, p. 21f.) and Thaler (2016, p. 29).

${ }^{2}$ Koller (2005, p. 106).

${ }^{3}$ Kelsen (1911, pp. 543-547).

${ }^{4}$ Merkl (1918). The „classical” version of the theory is given in Merkl (1931).

${ }^{5}$ Kelsen (1960, p. 313). The historical development oft he idea of the „Stufenbau” is described by Borowski (2005, pp. 124-131).

${ }^{6}$ See esp. the sum of Kelsen's theory in Kelsen (1967), and the chapter on „The dynamic aspect of law", pp. 193-278.

${ }^{7}$ Kelsen (1967, pp. 5-6).
} 
happen. But this would be a 'material-historical-psychological approach'. From the point of view of logic, there is no bridge that would lead from the one to the other. ${ }^{8}$

Therefore, it is in particular impossible to deduce from factual power relationships the validity of a norm. If a gangster says to me: "Give me your money!", and, because I am refusing to comply, uses force, he is perhaps only in gradual terms different from the income-tax official, who also wants my money and is prepared to use force, if necessary, to recover it. Nevertheless, the official's order, quite different to that of the gangster, will be interpreted as a norm. Behind his subjective volition there is an objective 'ought'. ${ }^{9}$ How can this be explained? What is the basis of the validity of this norm?

According to the Pure Theory of Law, the basis of the validity of this norm can only be another norm, which in our case authorises the officer to create norms. ${ }^{10}$ In our concrete case this would be a court order to direct a civil execution against someone's property. This only diverts the question for the basis of the validity, though. Now it sounds like this: What is the basis of the validity of the court order? If the court with which we are dealing here is situated in a continental European Rechtsstaat, a state under the rule of law, it will have applied a statute. And the norm which in turn provides for the validity of the statute is the constitution as the highest norm of the state. ${ }^{11}$ The word 'highest' does suggest a certain idea of spatiality, for whose characterisation the phrase 'hierarchical structure' is ideal; the entire legal order of the state appears as a hierarchy, with the constitution forming its highest level.

Obviously we cannot stop here, because the constitution must derive its validity from another norm, for example from a previous constitution, but this only works if this previous constitution included norms regulating how changes to the constitution should be made, and if these norms were actually applied. ${ }^{12}$ If the new constitution, however, has come about in a revolutionary act, then we have arrived at a provisional end point, at least as far as national law is concerned. I only want to hint here at the fact that another of Kelsen's disciples, Alfred Verdross, quite vehemently argued that national law has some norms of the international law as the basis of its validity. ${ }^{13}$ One could say that he extended the hierarchical structure from including only national law to comprising international law as well. Kelsen himself at least regarded this as one of several ways to solve the problem ${ }^{14}$; I myself share Verdross' opinion. But for us here it is not necessary to delve further into this discussion. In the present context we are only concerned with national law, and there, the constitution does indeed form the highest level of positive law. One level further down are the statutes, another level under them the ordinances or

\footnotetext{
${ }^{8}$ Kelsen (1911, p. 87).

${ }^{9}$ Kelsen $(1967$, p. 8$)$.

${ }^{10}$ Kelsen (1967, p. 193).

${ }^{11}$ Merkl (1931, p. 282).

${ }^{12}$ Kelsen (1967, p. 200).

${ }^{13}$ Verdross (1923, p. 134).

${ }^{14}$ Kelsen (1967, p. 336).
} 
administrative regulations, then the court decisions and individual administrative acts, and so on. ${ }^{15}$

The hierarchical structure which I have just described is a typical one, but not the only possible one. The actual sequence of the individual levels does not follow a principle of legal theory, but the positive law instead. ${ }^{16}$ This is why I said before, 'if the court with which we are dealing here is situated in a continental European Rechtsstaat, a state under the rule of law.' A court in a common law jurisdiction might not base its decision on a statute but on a precedent. A court in a fascist dictatorship might perhaps base its decision not on a statute but on the will of the dictator, which may have been issued only orally. The possibilities are endless.

It is crucial here to recognise that it is a characteristic of the law that it regulates its own creation. ${ }^{17} \mathrm{~A}$ highly developed legal order contains not just detailed rules which directly affect the coexistence of people but also equally detailed rules which authorise certain organs to create rules themselves. How detailed these rules are, how many levels there are in this hierarchical structure, entirely depends on the respective legal order. Always there has to be a highest level, which at least needs to state who is authorised to create law. But even if one imagines this norm in the simplest possible terms - for instance, regis voluntas suprema lex (the king's will is the supreme law $)^{18}$ - there needs to be at least one lower-level norm which contains some more specific expressions of the norm-issuer's will. Whether these are statutes, court decisions or administrative acts, whether a corresponding statute is needed to issue an administrative act, whether a difference is even made between a court decision and an administrative act - all these are questions of positive law, which may differ from one country to another. ${ }^{19}$ At any rate there needs to be a lowest level: the practical execution of a norm, which is the act in which the bailiff takes, for example, the laptop computer into his hands and carries it out of the apartment of the person against whom the execution is directed. This lowest level is not a norm; it is a legally relevant fact. ${ }^{20}$

Between the highest level, the constitution, and the lowest level, the factual execution of a norm, there are other norms whose creation is determined by a higher norm but which also serve as a precondition for the creation of lower-lever norms. While the highest level is a level of absolute law creation, and while the lowest level is a level of absolute law application, the levels in between have - to quote Merkl's famous dictum - 'two faces': they are law application (from the point of

\footnotetext{
${ }^{15}$ Merkl (1931, p. 259).

${ }^{16}$ Merkl (1931, p. 273).

${ }^{17}$ Kelsen (1929, p. 2), Merkl (1931, p. 281), Kelsen (1967, p. 221) and Vašek (2013, p. 10).

${ }^{18}$ Merkl (1931, p. 252).

${ }^{19}$ Kelsen (1929, p. 2).

${ }^{20}$ Merkl (1923, p. 2010), Merkl (1931, p. 260), Koller (2005, p. 109). See also Borowski (2005, p. 137f), who is on the opinion that it is not possible to construct a two-step legal order, so there has alway to be at least one level between the highest and the lowest one.
} 
view of the higher level) as well as law creation (from the point of view of the lower level). ${ }^{21}$

Law-creation from one level to the next was characterised by Merkl as a gradual individualisation and concretion ${ }^{22}$ : Very general norms develop gradually into more specialised ones; at first, they apply to an infinite number of material facts, then to a large number of them, then only to a few and eventually only to one. For example, the constitution only stipulates that the federal parliament is competent to create private law; private law stipulates that in the case of a divorce the child should stay with the parent who is best suited to bring him or her up; the judge finally needs to make a decision whether little Peter should be brought up by his father or by his mother. In this process, the creation of a new level is in part an act of thought, in part an act of will. ${ }^{23}$ In an act of thought, the legislator needs to understand the content of the constitution, the judge the content of the statute. One could say that these higher-level norms demarcate the outer frame of what is actually possible in terms of the law. Usually, this framework will allow for a number of alternatives. The legislator who is competent to create private law could also have said that divorce is illegal or that whenever a divorce occurs the child has to stay with his or her mother. But the legislator has found another solution, namely that the judge must decide which parent should bring up the child-this is the legislator's act of will. This means, however, that the judge is only dealing with a framework, he may decide in favour of the father as well as in favour of the mother, depending on what he thinks will be best for the welfare of the child.

At this point I should make a comment on the theory of interpretation that comes with the Pure Theory of Law ${ }^{24}$ : The highest principle of the Pure Theory of Law, as you know, is that it wants to 'purify' the study of the law of all non-juristic elements. It stipulates that only the 'act of thinking' just described, that is, the definition of the frame provided by the higher-level law, constitutes legal scholarship. This is true for the academic lawyer (for instance at a university) as well as for the practising law professional. The filling of this frame on the other hand, that is, the act of will in which a concrete decision is made, does not constitute scholarship but is an act of judgment which needs to follow extra-legal criteria. $^{25}$ In the language of the Pure Theory of Law, this is a 'political' act, but 'political' not in terms of party politics. At any rate, scholarship stops, as it were, one step before the goal; unlike the judge, it accepts that for an academic question there is often not one but there are several equally valid answers.

But let us now return to the hierarchical structure: The question on which level of the hierarchical structure a norm is situated is not determined based on its content but on its form: Constitutional provision-simple statute-ordinance-court

\footnotetext{
${ }^{21}$ Merkl (1918, p. 10).

${ }^{22}$ Merkl (1931, p. 283); see also Kelsen (1929, p. 3).

${ }^{23}$ Merkl (1923, p. 219).

${ }^{24}$ Kelsen (1967, pp. 348-356).

${ }^{25}$ Kelsen (1967, p. 351).
} 
decision or individual administrative act (formal administrative decision). It should be stressed at this point that court decisions and individual administrative acts are situated at the same level, that is, below the statute. In this respect, the theory of the hierarchical structure constitutes a counterpoint to the traditional theory of the separation of powers, which regards legislature, executive, and judiciary as standing next to each other and does not structure them hierarchically, whereas the theory of the hierarchical structure quite easily accounts for a precedence of the statute. ${ }^{26}$ This has led us to the core of our subject: the precedence of the constitution, which like the precedence of the statute can be understood in terms of the theory of the hierarchical structure.

The constitution is thus the level of the law which contains the preconditions according to which simple statutes can be created. ${ }^{27}$ One can distinguish two types of such preconditions: there are preconditions in regard to the legislative process on the one hand, and preconditions in regard to the content of the statutes on the other. $^{28}$ The constitution may contain provisions on who may initiate the legislative process, how many members of parliament need to be present during the poll, who needs the sign the bill once it has been passed, and so forth. It may also contain substantive provisions, however, in regard to a certain content that must not become law. One example is the distribution of competences in the federal state, which may prevent the federal parliament or the parliaments of the member states, respectively, from enacting laws on certain subjects. In particular, however, this concerns the fundamental rights and liberties, precisely because they are not written down in simple statutes but form part of the constitution, that is, rules which primarily address the legislator. They forbid him to overly restrict the freedom of speech, to discriminate against women, to impose the death penalty, etc.

This example, in particular, makes clear that we are referring to constitutional law in a formal sense, not to constitutional law in a substantial sense. ${ }^{29}$ If parliament enacted only a simple statute that says: 'Everyone is entitled to enjoy freedom of speech', and immediately afterwards another statute which imposes censorship on newspapers and other media, then the first statute could not block the second one. Only if the freedom of speech is constitutionally guaranteed, if in the hierarchical structure of the legal order it is one level above the statute, can it block the statute. However, this also means: if the statute that introduced censorship was itself enacted in the form of a constitutional provision, a constitutional guarantee against censorship will not have the desired effect, because the enabling and prohibiting norms are situated at the same level. ${ }^{30}$

Here again it should be noted that all of the examples provided depend on the respective national legal order. The example which I have chosen here is at any rate

\footnotetext{
${ }^{26}$ Merkl (1931, p. 285).

${ }^{27}$ Kelsen (1929, p. 7).

${ }^{28}$ Kelsen (1929, p. 8).

${ }^{29}$ Kelsen (1929, p. 7) and Kelsen (1967, p. 222).

${ }^{30}$ Kelsen $(1929,8,35)$.
} 
in accordance with the Austrian legal order. In Germany, the freedom of speech is guaranteed by Art. 5 of the Basic Law. This article is, at least to a certain extent, protected by the 'eternity clause' of Art. 79 of the Basic Law, which stipulates that the 'fundamental principles' of Art. 1-20 can never be changed. ${ }^{31}$ In the present context we need not delve into the question of what precisely these 'fundamental principles' are or which limitations to the freedom of speech might be introduced even in the Federal Republic of Germany by means of a constitutional amendment. We can however note that there seem to be in Germany two types of constitutional law: Constitutional law which is affected by the eternity clause, on the one hand, and all the other constitutional law, on the other. This necessarily implies that even within constitutional law, separate levels may exist, and that Art. 79 constitutes as it were the highest level of national law. The Austrian counterpart would be the 'structural principles' of the Austrian Federal Constitution. This idea was developed by legal theorists on the basis of Art. 44 of the Federal Constitutional Act; it stipulates that a fundamental change to the democratic, republican, federal, or other basic principle of the constitution requires a two-thirds majority in parliament as well as a referendum. The point is that by means of this complicated procedure a total change of the constitution would at least theoretically be possible, which is not the case in Germany. ${ }^{32}$

But what are the implications then if a statute was passed in a procedure that deviated from the procedure laid down in the constitution, or if it has some content that is ruled out by the constitution? Given that the constitution sets the preconditions under which statutes can come into existence, the answer must primarily be that any deviation from these preconditions, as small as it may be, must have as its consequence that the statute has not accrued the force of law, that is, that it is null and void. ${ }^{33}$ The argument was also a similar one in the US Supreme Court case Marbury v. Madison, where the court came to the conclusion that the Act in question was null and void. ${ }^{34}$

This state of affairs will only be different if the constitution contains a provision which expressly prohibits the courts to exercise judicial reviews of statutes or at least contains a prohibition of reviewing statutes in terms of their content. Such prohibitions could be found in many constitutions of the nineteenth and twentieth centuries and seemingly had the effect that the judges had to apply statutes even if they were clearly unconstitutional. ${ }^{35}$ But was that indeed the case?

Let us remind ourselves of the significance of the hierarchical structure of the legal order. This stepped pyramid traces all legal acts in the state back to higher-level legal acts and these are traced back to the constitution. The constitution

\footnotetext{
${ }^{31}$ See Dreier (1994, p. 265ff.), with further references; Vašek (2013, p. 30).

${ }^{32}$ See now the sharp-witted analysis by Vašek (2013).

${ }^{33}$ Kelsen (1929, p. 15) and Merkl (1923, p. 292).

${ }^{34}$ Urofsky and Finkelman (2002), Documents No. 46.

${ }^{35}$ See for example article 7 of the Austrian Staatsgrundgesetz über die richterliche Gewalt, 21st December 1867, Reichsgesetzblatt No. 144.
} 
is the origin of all national law, it provides for the unity of the legal order, figuratively speaking: it expresses the will of the state. An unconstitutional statute is characterised by the facts that it cannot be incorporated into the hierarchical structure; that it cannot base its validity on the constitution; that it does not reflect the will of the state.

But if the constitution says: 'I want you to apply this law, and whether its content is compatible with the provisions which I have made elsewhere does not need to concern you', then it is the will of the constitution that this apparently unconstitutional statute should be valid. But in this case the statute is not unconstitutional at all, it is indeed constitutional.

Here an example as well: If the constitution says that freedom of speech is guaranteed and a statute introduces censorship, then this statute is unconstitutional and therefor null and void. If the constitution however also says that the judges must not review the censorship statute, then this statute is constitutional and valid. The question that remains to be asked then is: To what extent is the guaranteed freedom of speech still significant? The answer is rather frustrating: This constitutionally guaranteed right has no significance vis-a-vis the simple legislator, it cannot bind him. In other words, in the hierarchical structure of the legal order it is not above but at the same level as the censorship statute. By means of the simple sentence: 'Judges are not competent to carry out judicial review', the differentiation between constitutional law and simple statutes loses its significance, and even more: it does not exist.

And this is exactly the point where Hans Kelsen's concept of constitutional courts sets in. As soon as there is a court which is competent to review the constitutionality of statutes, this introduces also a special level of formal constitutional law in the hierarchical structure of the legal order. ${ }^{36}$ This constitutional court simply checks whether the preconditions for the creation of statutes as stipulated in the constitution have been met. If the constitution offers the simple legislator several alternatives and if the legislator has chosen one of these legitimate alternatives, then the constitutional court must not criticise this choice; it is not the legislator's choice which is under review, but only whether he has remained within the framework of the constitution. Its role is not different to that of a court of higher instance, which reviews the decision of the court of first instance but may only decide whether the decision was legally correct, but not whether it was lenient or harsh, fair or unfair. ${ }^{37}$

The particularity of the Austrian model of judicial review by a constitutional court, by which it differs from the American model, is its centralisation in a single court: All the other courts cannot undertake the judicial review themselves; they may only request that the constitutional court, which has a monopoly in this respect, checks a statute for its constitutionality. ${ }^{38}$ If it comes to the conclusion that a statute is unconstitutional, it annuls this statute. This means that its decisions have a

\footnotetext{
${ }^{36}$ Kelsen (1929, p. 48).

${ }^{37}$ Kelsen (1931, p. 71).

${ }^{38}$ Olechowski (2014, p. 87).
} 
constitutive effect; the statute is not invalidated until it is declared null and void. Until then it is only annullable, or in other words, not an absolute but a relative nullity. ${ }^{39}$

How can this provision be understood in terms of the hierarchical structure? Annulment is only an option for something which has previously existed. This means that until they are annulled, unconstitutional statutes are valid. And this also corresponds to the prohibition directed at other courts to undertake the judicial review themselves. So the constitution does, as just explained, indeed contain a general sanction according to which statutes, as long as they have the outward appearance of a statute, have at least provisional validity, even if they are otherwise flawed. For this phenomenon, Merkl coined the term Fehlerkalkül, which means that the constitution takes the possible faultiness of statutes into account and merely provides for the possibility of their annulment by a special court. ${ }^{40}$

With this I am arriving at the last aspect: I have made use of the hierarchical structure in two different ways ${ }^{41}$ : On the one hand, it shows how the entire legal order consists of norms which are in a relation of super- and sub-ordination; one norm owes its validity to the validity of another norm. On the other hand, however, the hierarchical structure provides also the theoretical basis for the annulment of statutes; higher-level law destroys lower-level law. It must be clear that the hierarchical structure understood in terms of legal conditionality does not have to be completely identical with the hierarchical structure understood in terms of derogatory power. ${ }^{42}$ A constitutional provision can form the basis for the annulment of a simple statute even if it was created after the statute and thus cannot have been a precondition for the creation of this statute in the first place. A converse example would be the parliamentary rules of procedure, which will usually either be at a lower level or at most at the same level as a simple statute, but which are also a precondition for the creation of simple statutes and even constitutional provisions. It is thus justified to join Merkl in distinguishing between two 'hierarchical constructions': the hierarchical structure understood in terms of legal conditionality and the hierarchical structure understood in terms of derogatory power. In both of them, however, the constitution will claim the highest level.

\section{References}

Borowski M (2005) Die Lehre vom Stufenbau des Rechts nach Adolf Julius Merkl. In: Paulson, SL, Stolleis M (eds) Hans Kelsen. Staatsrechtslehrer und Rechtstheoretiker des 20. Jahrhunderts. Tübingen, pp 122-159

\footnotetext{
${ }^{39}$ Kelsen (1929, p. 15).

${ }^{40}$ Merkl (1923, p. 293), Merkl (1931, p. 293) and Borowski (2005, p. 151).

${ }^{41}$ Merkl (1931, p. 278).

${ }^{42}$ Merkl (1931, p. 278); this is criticized by Koller (2005, p. 112).
} 
Dreier H (1994) Grenzen demokratischer Freiheit im Verfassungsstaat. Reprint in Horst Dreier, Idee und Gestalt des freiheitlichen Verfassungsstaates. Tübingen 2014. pp 249-285

Kelsen H (1911) Hauptprobleme der Staatsrechtslehre. Reprint in Jestaedt M (ed) (2008) Hans Kelsen Werke. Tübingen, pp 21-878

Kelsen H (1929) Wesen und Entwicklung der Staatsgerichtsbarkeit. Reprint in Van Ooyen RC (ed) (2008) Wer soll Hüter der Verfassung sein? Tübingen, pp 1-57

Kelsen H (1931) Wer soll der Hüter der Verfassung sein? Reprint in Van Ooyen RC (ed) (2008) Wer soll Hüter der Verfassung sein? Tübingen, pp 58-105

Kelsen H (1960) Adolf Merkl zu seinem siebzigsten Geburtstag am 23. März 1960. Österreichische Zeitschrift für Öffentliches Recht. Neue Folge 10:313-315

Kelsen H (1967) Pure theory of law. Translation from the Second (Revised and Enlarged) German Edition by Max Knight. Berkeley, Los Angeles

Kneihs B, Bydlinski P, Vollmaier P (2014) Einführung in das österreichische Recht, 2nd edn. Wien

Koller P (2005) Zur Theorie des rechtlichen Stufenbaues. In: Paulson SL, Stolleis M (eds) Hans Kelsen. Staatsrechtslehrer und Rechtstheoretiker des 20. Jahrhunderts. Tübingen, pp 106-121

Merkl A (1918) Das doppelte Rechtsantlitz. Eine Betrachtung aus der Erkenntnistheorie des Rechtes. Juristische Blätter 47:425-427, 444-447, 463-465

Merkl A (1923) Die Lehre von der Rechtskraft. Wien, Leipzig

Merkl A (1931) Prolegomena einer Theorie des rechtlichen Stufenbaues. In: Verdross A (ed) Gesellschaft, Staat und Recht. Untersuchungen zur Reinen Rechtslehre, pp 252-294

Olechowski T (2014) The beginnings of constitutional justice in Europe. In: Madsen M, Thornhill C (eds) Law and the formation of modern Europe: perspectives from the historical sociology of law. Cambridge, pp 77-95

Thaler M (2016) Grundlagen von Verfassungs- und Verwaltungsrecht: eine rechtsvergleichende Einführung zum Verständnis. 2nd edn. Wien

Urofsky M, Finkelman P (eds) (2002) Documents of American constitutional and legal history. New York, Oxford

Vašek M (2013) Unabänderliches Verfassungsrecht und Revisionsschranken in der österreichischen Bundesverfassung. Wien

Verdross A (1923) Die Einheit des rechtlichen Weltbildes auf Grundlage der Völkerrechtsverfassung. Tübingen

Open Access This chapter is licensed under the terms of the Creative Commons Attribution 4.0 International License (http://creativecommons.org/licenses/by/4.0/), which permits use, sharing, adaptation, distribution and reproduction in any medium or format, as long as you give appropriate credit to the original author(s) and the source, provide a link to the Creative Commons license and indicate if changes were made.

The images or other third party material in this chapter are included in the chapter's Creative Commons license, unless indicated otherwise in a credit line to the material. If material is not included in the chapter's Creative Commons license and your intended use is not permitted by statutory regulation or exceeds the permitted use, you will need to obtain permission directly from the copyright holder.

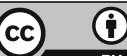

